\title{
Diabetic Coma: Some Problems Not Solved By The Nobel Prize 1923
}

\author{
Viktor Rosival* \\ Department of Laboratory Medicine, Slovakia
}

*Corresponding author: Viktor Rosival, SYNLAB Department of Laboratory Medicine, Dérer's Hospital, Limbová 5, SK-833 05 Bratislava, Slovakia

\begin{tabular}{lll}
\hline ARTICLE INFO & & ABSTRACT \\
\cline { 1 - 1 } $\begin{array}{l}\text { Received: 幽 October 25, } 2019 \\
\text { Published: }\end{array}$ & & $\begin{array}{l}\text { Citation: Viktor Rosival. Diabetic Coma: Some Problems Not Solved By The Nobel Prize } \\
\text { 1923. Biomed J Sci \& Tech Res 22(3)-2019. BJSTR. MS.ID.003759. }\end{array}$ \\
\hline
\end{tabular}

\section{Introduction}

At the beginning of the $20^{\text {th }}$ century, two diseases had $100 \%$ lethality: pernicious anemia and diabetic coma. Between the two World wars substantial progress in their treatment has been honoured with Nobel prizes.Today, at the beginning of the 21th century, nobody remembers lethal outcome in a patient with pernicious anemia, whereas between 1990 and 2010 in USA died yearly 2000-3000 patients in "hyperglycemic crises“ despite the availability of insulin therapy [1]. Was the Nobel prize 1923 to Banting and Macleod an error? It is very complicated to explain this unexpected reality. Lethal coma in diabetes has been first reported 1874 by Kussmaul [2]. 3 patients, 16-35 years old, with diabetes mellitus, died in coma; in one of them was aceton in his urine. Already 1881 and 1886 has Dreschfeld [3,4]. emphasized that coma in diabetic patients occurs not only with aceton and acetoacetic acid in their urine, but also without them in their urine. Unfortunately, these facta have not been noted until 1957 after a case-history reported from South Africa [5]. It is interesting that this report did not come from the USA or Europe, where many diabetologists were active and it is very difficult to understand why the world diabetology has not accepted coma without ketoacidosis according to the paper of Dreschfeld.

Very good exemple for existence of coma without aceton is the paper of Rolly [6] from 1913: at this time, it was already possible to measure $\mathrm{pH}$ of the blood; in 11 comatose diabetic patients only 3 patients had acidosis. After the paper of Sament and Schwartz [7]. a,new interpretation" of the two kinds of diabetic coma was necessary: "decrease" of insulin cocncentration in the blood is the cause of non-ketotic hyperglycemic coma and "absolute“ deficiency of insulin in the blood is the cause of ketoacidotic coma. A definitve solution was possible only after the Nobel prize 1977 to Rosalyn S. Yalow for development of new methods of biochemical analysis that make possible to measure insulin concentration in human plasma. In patients with diabtic ketoacidosis have been observed sufficient amounts of plasmatic insulin, e g [7]. On the other hand, absolute deficiency of plasmatic insulin has been reported also in diabetic patients with hyperglycemic hyperosmolar non ketotic coma, e g [8]. and in diabetic patients on routine control, without subjective complaints, e $g$ [9]. Thus, insulin deficiency is not the cause of ketoacidosis. As the cause of diabetic ketoacidosis and coma has been identified low blood-pH [10]. and this has been confirmed in both pediatric [11]. and adult [12]. patients. The validity of this observation is confirmed by zero lethality of patients in diabetic ketoacidotic coma after treatment with infusions of sodium bicarbonate, e g [13]. The decrease of blood-pH is caused by increased amouts of 36 organic acids [14]. In conclusion, insulin treatment is successfully life-saving in hyperosmolar hyperglycemic non-ketotic coma, whereas in ketoacidotic coma is life-saving treatment with alkalising solutions such as sodium bicarbonate.

\section{References}

1. Gregg EW, Li Y, Wong J (2014) Changes in diabetes-related complications in the United States N Engl J Med 370: 1514-1523.

2. Kussmaul A (1874) Zur Lehre vom Diabetes mellitus. Dtsch Arch Klin Med 14: 1-47.

3. Dreschfeld J (1881) Reports of societies: Manchester medical society. Brit Med J 2: 710.

4. Dreschfeld J (1886) The Bradshaw Lecture on Diabetic Coma. Brit. Med 2: 358-363.

5. Sament S, Schwartz MD (1957) Severe diabetic stupor without ketosis. South African Med J 31: 893-894. 
6. Rolly F (1913) Das Wesen und die Behandlung des Coma diabeticum Med Klinik.

7. Schade DS, Eaton RP, Alberti KGMM (1981) Diabetic coma: ketoacidotic and hyperosmolar. University of New Mexico Press, Albuquerque, Mexico.

8. Vinik A, Seftel H, Joffe BI (1970) Metabolic findngs in hyperosmolar nonketotic diabetic stupor. Lancet 2: 797-799.

9. Matsuyama T, Hoffman WH, Dunbar JL (1975) Glucose, insulin, pancreatic glucagon and glucagon-like immunoreactive materials in the plasma of normal and diabetic children. Horm Metab Res 7: 452-456.

10. Rosival V (1987) The influence of blood hydrogen ion concentation on the level of consciousness in diabetic ketoacidosis. Annals of Clinical Research 19: 23-25.

ISSN: 2574-1241

DOI: 10.26717/BJSTR.2019.22.003759

Viktor Rosival. Biomed J Sci \& Tech Res

This work is licensed under Creative Commons Attribution 4.0 License

Submission Link: https://biomedres.us/submit-manuscript.php
11. Edge JA, Roy Y, Bergomi A (2006) Conscious level in children with diabetic ketacidosis is related to severity of acidosis and not to blood glucose concentration. Pediatr Diabetes 7: 11-13.

12. Nyenwe EA, Khan AN, Razavi LN, Khan AN, Wan JY, et al. (2010) Acidosis: The Prime Determinant of Depressed Sensorium in Diabetic Ketoacidosis. Diabetes Care 33:1837-1839.

13. Umpierrez GE, Kelly JP, Navarrete JE (1997) Hyperglycemic crises in urban blacks. Arch. Intern. Med 157: 669-675.

14. Niwa T (1995) Mass spectrometry in diabetes mellitus. Clin Chim Acta 241: $190-220$

$\begin{array}{ll}\text { BIOMEDICAL } & \text { Assets of Publishing with us } \\ \text { RESEARCHES } & \text { - Global archiving of articles } \\ & \text { - Immediate, unrestricted online access } \\ & \text { - Rigorous Peer Review Process } \\ \end{array}$

